\title{
Speaking in Tongues: Can International Graduate Students Read International Graduate Admissions Materials?
}

\author{
Zachary W. Taylor ${ }^{1}$ \\ ${ }^{1}$ The University of Texas at Austin, USA \\ Correspondence: Zachary W. Taylor, The University of Texas at Austin, College of Education, 1912 Speedway, Stop \\ D5000, Austin Texas, 78712 USA \\ Received: May 1, 2017 \\ Accepted: May 21, 2017 \\ Online Published: May 25, 2017 \\ doi:10.5430/ijhe.v6n3p99 \\ URL: https://doi.org/10.5430/ijhe.v6n3p99
}

\begin{abstract}
A recent Educational Testing Services report (2016) found that international graduate students with a TOEFL score of 80 - the minimum average TOEFL score for graduate admission in the United States-usually possess reading subscores of 20 , equating to a $12^{\text {th }}$-grade reading comprehension level. However, one public flagship university's international graduate student admissions instructions are written at a $17^{\text {th }}$-grade reading comprehension level, or, a 27-30 band on the reading section of the TOEFL. This study seeks to answer the question, "Do U.S. graduate programs compose admissions materials at unreadable levels compared to these programs' minimum reading comprehension levels for international graduate student admission?" Findings reveal average public flagship international graduate student admissions materials are written above $15^{\text {th }}$-grade reading comprehension levels, with select flagships composing these materials at 19th grade reading levels. Implications for practitioners and policymakers, as well as areas of future research, are addressed.
\end{abstract}

Keywords: Admissions materials, International students, Graduate students, Readability, Higher education

\section{Introduction}

For the first time ever, during the 2015-2016 academic year, the postsecondary international student population in the United States eclipsed one million students. Of these over one million students, 98\% arrive from countries whose first national language is not English (Institute of International Education, 2016). To screen these students, United States graduate programs require English proficiency on the Test of English as a Foreign Language (TOEFL) and/or International English Language Testing System (IELTS) prior to admission, a practice dating back to the early 1960s (Educational Testing Service, 2016).

In 2016, American Exam Services conducted a survey of 353 public and private graduate schools in the United States and found that these graduate schools require a minimum, cumulative TOEFL score ranging from 53 to 111 , combined from TOEFL subscores in reading, listening, speaking, and writing sections. Of course, these scores mean little to those unfamiliar with the TOEFL and the levels of English competency that each score represents. However, in 2010, a team of researchers at Educational Testing Services (ETS) published a report comparing TOEFL scores to the Lexile measures, thus producing the first TOEFL to grade-level reading comprehension scale. The report found that a TOEFL reading score of 27-30 equated to a $1490 \mathrm{~L}-1595 \mathrm{~L}$ band, or, " $16^{\text {th }}$-grade" graduate-level reading comprehension, with TOEFL scores 22-26 equating to college junior- and senior-level reading comprehension, 18-21 equating to high school senior-level reading comprehension, 15-17 equating to high school sophomore-level reading comprehension, 9-14 equating to middle school eighth grade-level reading comprehension, and 0-8 equating to middle school sixth grade-level reading comprehension (Wendler, Cline, Sanford, \& Aguirre, 2010).

Understanding that 353 public and private United States graduate schools require minimum TOEFL scores ranging from 53-111, specific reading subscores are difficult to deduce. However, an ETS report (2016) found that international graduate students with a TOEFL of 80 - the minimum average TOEFL score for graduate admission in the United States-usually possess reading subscores around 20, including international students entering business, non-business, and English language only schools. Using Wendler et al.'s (2010) findings, a reading subscore of 20 equates to high school junior- or senior-level reading comprehension.

In short, the average graduate program in the United States requires incoming international graduate students to read at high school junior or senior levels of reading comprehension. This is problematic for a simple reason. 
Preliminary research reveals the University of Texas at Austin's international graduate student admissions instructions are written at a $17^{\text {th }}$-grade reading level (The University of Texas at Austin Graduate School, 2017) according to Flesch-Kincaid, Gunning-Fog, and SMOG readability indices, three of the most commonly-used and rigorously-researched readability measures in existence. For a direct comparison to Wendler et al.'s (2010) work, UT-Austin's instructions are written at a Lexile of 1490L, or, a 27-30 band on the reading section of the TOEFL. Yet, UT-Austin only requires a composite TOEFL score of 79, or, a 19-20 on the TOEFL reading subsection for international graduate admission.

In short, UT-Austin composes their international graduate admissions instructions at a far more difficult reading comprehension level than the UT-Austin Graduate School requires from international graduate students on the TOEFL reading test.

Educational researchers must couple this initial finding with the recent political turmoil in the United States. Mere months after President Donald Trump's rapid-fire Executive Orders exercised the Immigration and Nationality Act (Trump, 2017a, 2017b, 2017c), U.S. graduate programs experienced a sharp decline in applications from international students, as nearly $40 \%$ of U.S. universities reported a drop in international applicants, particularly from the Middle East (Advancing Global Higher Education, 2017). Even though international graduate students are enrolled in United States' institutions at an all-time high, perhaps in no other time in U.S. history do U.S. graduate programs and schools need to facilitate equitable, comprehensible admissions processes for international students. Readability of international graduate admissions materials is crucial in this regard.

To ensure an equitable, transparent admissions process for all international graduate students entering U.S. graduate programs, this study performs a national-level linguistic analysis of international graduate student admissions materials of public flagship institutions $(n=50)$ made available on institutional websites, representing the first project of its kind. As a new, salient line of inquiry, these electronic resources are appropriate semantic spaces for linguistic analysis, as extant research supports the notion that postsecondary students from all backgrounds first explore online admissions resources and materials before engaging in any other form of communication with postsecondary institutions (Burdett, 2013). Therefore, this study employs five canonical readability measures to answer the research question, "Do U.S. graduate programs compose admissions materials at unreadable levels compared to these programs' minimum reading comprehension levels for international graduate student admission?"

\section{Studies in Readability}

Although studies of readability and its implications for international graduate students have been overlooked by the field of higher education, foundational work regarding the readability of a wide variety of textual information has existed for nearly a century. In 2004, William DuBay published The Principles of Readability, providing a comprehensive overview of readability formulas and their usage, articulating the widespread, and still current, use of readability formulas across countless disciplines and industries.

Readability as a field of research began in the 1920s, when educators and research scientists discovered a method of combining diction difficulty with sentence length and structure to predict the readability difficulty of a given text. By the 1950s, writers and researchers like Rudolf Flesch, Edgar Dale, and Jean Chall pushed readability formulas into the mainstream marketplace, which were subsequently used for journalistic (Clark, Kaminski, \& Brown, 1990), law (Milne, Culnan, \& Greene, 2006), insurance (Walfish \& Watkins, 2005), and industry standards (Loughran \& McDonald, 2014). However, two of the largest enterprises to heavily use readability measures since their marketplace entry are the United States Armed Forces and the healthcare industry.

Since the 1950s, United States citizens must pass a literacy test to join any branch of the Armed Forces. In the 1970s, a computational error resulted in the recruitment of nearly 200,000 service candidates in the lowest literacy category, but Congress decided to retain them and create workplace literacy programs, which led to the educational enrichment and subsequent promotion of soldiers (DuBay, 2004). Ultimately, the adoption of readability tests to measure military communication began in the 1970s when the United States Department of Defense began using the Flesch-Kincaid and Dale-Chall measures to compose their publicly-disseminated literature at an $8^{\text {th }}$-grade reading comprehension level (Caylor, Sticht, Fox, \& Ford, 1973) and was researched thoroughly in subsequent years (Carver, 1974; Fry, 1986; Johnson, 1972; Kniffin, 1979; McClure, 1987; Sticht, 1970; Sticht \& Zapf, 1976).

In addition to military purposes, readability tests have been implemented by the healthcare field for decades for a variety of purposes (Hendrickson, Huebner, \& Riedy, 2006; Ley \& Florio, 1996; Lowery \& Martin, 1990). In recent years, healthcare-related readability studies have focused on the impact of readability as it pertains to the clarity of wellness services received and rendered by the patient, such as the examination of doctor-to-patient e-communications 
(Mirsky, Tieu, Lyles, \& Sarkar, 2015), privacy policies (Ermakova, Fabian, \& Babina, 2015), healthcare literature (Meillier, Patel, \& Al-Osaimi, 2015), cancer information (Ibrahim, Vargas, Koolen, Chuang, Lin, \& Lee, 2016), and the integration of healthcare materials into social media platforms and applications (Lopez, Blobel, \& Gonzalez, 2016).

Yet the study of readability at the postsecondary level is extremely limited to the appropriateness of textbooks selected and used by course instructors. Cline (1973) found that 52\% of students in a community college in mid-Missouri had reading abilities below the grade-level readability of textbooks used in their classes. Shepherd, Selden, and Selden (2011) demonstrated incoming college students with high ACT reading comprehension scores were not proficient readers of collegiate-level mathematics textbooks. Schneider (2011) examined the readability of public speaking textbooks and found that readability levels of 22 nationally published textbooks were written at the $15^{\text {th }}$-grade level, more difficult than a college freshman ought to expect to comprehend. Burton (2014) studied the technical variety of college science textbooks and found that textbooks were not a critical source of student learning, nor did students demonstrate a high level of reading comprehension when examined. However, Peng (2015) found that a student's age, major, degree plan, and hours worked outside of school were more significant determinants on student performance than the readability of their textbooks through coursework. Ultimately, the last fifty years of postsecondary readability research has focused on one phenomenon of the collegiate experience - textbooks - and little else.

\section{Positive Impacts of International Graduate Students in U.S. Graduate Programs}

Extant research has demonstrated the positive impacts of international students on United States' competitiveness in STEM (science, technology, engineering, and mathematics) disciplines, namely computer science and electrical engineering. Specifically focused at the graduate level, all United States computer science graduate programs enrolled a $79 \%$ majority international student body, and electrical engineering graduate programs enrolled an $88 \%$ majority international student body (Anderson, 2013). International students also positively impact research funding and faculty retention, as a 2010 National Science Foundation study found international graduate students often assuage burdensome research and publication duties thrust upon tenure-track and tenured faculty, allowing university professors and institutional researchers the resources to procure external funding and retain high quality faculty members, thus improving the educational experience for all students (Kang, 2013). In short, international graduate students' academic contributions to United States graduate programs are voluminous.

However, international graduate students' perhaps most valuable contribution to the United States postsecondary education system is a learned, lived ambassadorship of American culture, which augments American acumen in an increasingly international labor market, promoting a sense of "global competency" for all educational stakeholders in the United States (Pandit, 2007). Here, international graduate students serve as diplomatic conduits, socially and economically connecting the United States postsecondary system to the rest of the world.

\section{Methodology}

Because the evaluation of university-authored international graduate admissions materials is a new field of inquiry, no readability tests specifically targeting such documentation currently exist. Therefore, this study aims to best triangulate the readability of each webpage by employing several industry-accepted, commonly-used readability measures in tandem and then averaging their results. In addition, each readability measure is nuanced and examines different elements of text, allowing for accurate, semantically and syntactically triangulated estimates.

The Automated Readability Index (ARI) is a measure of readability difficulty that calculates the grade level of narrative texts, examining the average word and sentence length of a given selection of text. The use of the ARI for this study's purpose is validated by its appropriateness for adult-level textual analysis, given the ARI's implementation by the Army National Guard and other branches of the United States Department of Defense (Kincaid \& Delionbach, 1973). ARI is measured thus: $\mathrm{G}=(4.71 *(\mathrm{RP} / \mathrm{W}))+(0.5 *(\mathrm{~W} / \mathrm{S}))-21.43$, where $\mathrm{G}=$ grade level, $\mathrm{W}=$ number of words, $\mathrm{RP}=$ number of strokes (characters and punctuation less sentence terminating punctuation i.e. periods), and $\mathrm{S}=$ number of sentences.

The Flesch-Kincaid Grade Level Test (FK) is a measure of readability difficulty that calculates the grade level of technical documents and nonfiction based on sentence length and syllable count. The use of FK for this study's purpose is validated by its longitudinal use (40 years) by the United States Navy in its evaluation of the reading levels of entry-level and experienced naval cadets (Kincaid, Fishburne, Rogers, \& Chissom, 1975). FK is measured thus: $\mathrm{G}=$ $(11.8 *(\mathrm{~B} / \mathrm{W}))+(.39 *(\mathrm{~W} / \mathrm{S}))-15.59$, where $\mathrm{G}=$ grade level, $\mathrm{W}=$ number of words, $\mathrm{B}=$ number of syllables, and $\mathrm{S}=$ number of sentences.

The Gunning-Fog Index (GFI) is a measure of readability difficulty that calculates the grade level of a document based on numbers of sentences and complex words, defined as words that contain three or more syllables except for proper 
nouns, words made three syllables by adding the inflections "-ed" and "-es," and compound words composed of simpler words, i.e. horsepower = "horse" + "power" (Gunning, 1952). The use of the GFI for this study's purpose is validated by its widespread use across a variety of disciplines for over forty years (Schlief \& Wood; 1974; Strong, 1986; Wong, 1999). GFI is measured thus: $\mathrm{G}=.4 *\left(\mathrm{~W} / \mathrm{S}+\left((\mathrm{C} / \mathrm{W})^{*} 100\right)\right)$, where $\mathrm{G}=$ grade level, $\mathrm{W}=$ number of words, $\mathrm{C}=$ number of complex words, and $\mathrm{S}=$ number of sentences.

The Simple Measure of Gobbledygook Readability Formula (SMOG) is a measure of readability difficulty that calculates the grade level of any document at least 30 sentences in length based on the number of complex words and total sentences. A complex word is defined as one with three or more syllables, with complex sentences featuring a semicolon counted as two sentences (McLaughlin, 1969). The use of the SMOG for this study's purpose is validated by its widespread use across a variety of disciplines for over forty years, especially the healthcare field where complex jargon (gobbledygook) is commonly used to describe medical conditions. SMOG is measured thus: $\mathrm{G}=\mathrm{C}$ per 30 sentence passage, where $\mathrm{G}=$ grade level, and $\mathrm{C}=$ number of complex words (three syllables or more) using SMOG's proprietary conversion table.

The Lexile Text Measure (LEXILE, stylized as 400L or 1350L) is a measure of readability difficulty that calculates the grade level (Lexile scale) of any document based on word frequency and sentence length. The word frequency of a given document is cross-referenced with a proprietary textual database that helps determine how difficult or familiar a word might be for students from kindergarten through $12^{\text {th }}$ grade, with no explicit grade level ceiling. It is also important to note that when Lexile measures and the Lexile scale were developed, a 75\% comprehension rate was used. For example, if a student with a Lexile of $600 \mathrm{~L}$ reads a text composed at $600 \mathrm{~L}$, it is expected that the student will be able to read and comprehend $75 \%$ of the text (MetaMetrics, 2007). The use of Lexile levels for this study's purpose is validated by its direct use to compare TOEFL reading comprehension scores to Lexile reading comprehension levels (Wendler et al., 2010). Lexile is measured thus: Theoretical Logit $=(9.82247 *$ LMSL)-(2.14634*MLWF)-constant where, $\mathrm{LMSL}=\log$ of the mean sentence length, MLWF = mean of the log word frequencies, and LMSL and MLWF are used as proxies for syntactic complexity and semantic demand. The logits anchored in the equation above translate into Lexiles with the following formula: Lexile calibration $=(\operatorname{logit}+3.3) * 180+200$ (Burdick \& MetaMetrics, 2010).

Three software suites were used for this study for various purposes. First, Readability Studio, a computer-aided text analysis software, was used to calculate the ARI, FK, GFI, and SMOG of each website and/or document by entering the host URL or manually extracting and uploading the appropriate text. However, Readability Studio cannot decode HTTPS encryption protocol, so those websites had their text extracted manually and entered into the software program for analysis. Second, the Lexile Analyzer (https://lexile.com/analyzer/) was used to calculate the Lexile level of each website by extracting a 150-word passage from the website, converting the data into a plain text (.txt) file, and uploading it into the software program. Then, MetaMetrics' Lexile-to-Grade Correspondence measure was employed to find the grade level indicated by the Lexile level (MetaMetrics, 2016). According to their website, results from the Lexile Analyzer cannot be reproduced or reported, however, I received written consent from MetaMetrics in September 2016 to publish the results of the Lexile Analyzer, as well as my research findings.

\section{Data}

In order to answer my research question-Do U.S. graduate programs compose admissions materials at unreadable levels compared to these programs' minimum reading comprehension levels for international graduate student admission?-I simply used each public flagship's institutional search tool and entered "international graduate admissions requirements," successfully locating the webpage a prospective international graduate student would likely visit during the pre-enrollment "search" period (Hossler \& Gallagher, 1987). Each institution's international graduate admissions requirements webpage included application completion information, minimum test scores, fees, and methods of submitting test scores and official transcripts. From these institutional webpages, I extracted minimum TOEFL scores for international graduate student admission: this database is available upon demand from the author.

Because of this institutional search, the data used for this study come from three sources: (1) institutional text data extracted from each university's “.edu” domain, current as of March 2017; (2) readability scores calculated by the Readability Studio software suite; (3) Lexile levels calculated by MetaMetrics and the Lexile Analyzer software suite.

I selected public flagship universities for this study based on several criteria. First, after a preliminary investigation, I learned all public flagships enroll international graduate students. These universities also feature international graduate student webpages on their institutional websites, with corresponding resources, centers, or departments on campus. Second, I wanted to examine postsecondary institutions from different geographic regions with access to socioeconomically and ethnically diverse populations, representing attractive, multicultural landing spots for prospective international graduate students. Finally, and perhaps most importantly, public flagships are generally 
considered the leading research institutions in their state (Berdahl, 1998; Fox, 2001), and therefore, may appear more attractive for international graduate students than other types of institutions of higher education, especially given international graduate students' positive impact on U.S. graduate programs' research output (Kang, 2013). A listing of public flagship universities examined in this study can be found in Table 1 below.

Table 1. List of public flagship universities in the United States

\begin{tabular}{|c|c|c|c|}
\hline State & Institution & State (cont'd) & Institution \\
\hline Alabama & U of Alabama & Montana & U of Montana \\
\hline Alaska & U of Alaska, Fairbanks & Nebraska & U of Nebraska, Lincoln \\
\hline Arizona & $\mathrm{U}$ of Arizona & Nevada & U of Nevada, Las Vegas \\
\hline Arkansas & U of Arkansas & New Hampshire & U of New Hampshire \\
\hline California & U of California, Berkeley & New Jersey & Rutgers \\
\hline Colorado & U of Colorado, Boulder & New Mexico & $\mathrm{U}$ of New Mexico \\
\hline Connecticut & $\mathrm{U}$ of Connecticut & New York & SUNY, Buffalo \\
\hline Delaware & U of Delaware & North Carolina & UNC, Chapel Hill \\
\hline Florida & $\mathrm{U}$ of Florida & North Dakota & U of North Dakota \\
\hline Georgia & $\mathrm{U}$ of Georgia & Ohio & Ohio State U \\
\hline Hawaii & U of Hawaii, Manoa & Oklahoma & U of Oklahoma \\
\hline Idaho & $\mathrm{U}$ of Idaho & Oregon & $\mathrm{U}$ of Oregon \\
\hline Illinois & U of Illinois, Urbana-Champaign & Pennsylvania & Pennsylvania State U \\
\hline Indiana & IU Bloomington & Rhode Island & U of Rhode Island \\
\hline Iowa & U of Iowa & South Carolina & USC, Columbia \\
\hline Kansas & U of Kansas & South Dakota & U of South Dakota \\
\hline Kentucky & U of Kentucky & Tennessee & U of Tennessee, Knoxville \\
\hline Louisiana & Louisiana State U & Texas & $\mathrm{U}$ of Texas, Austin \\
\hline Maine & U of Maine & Utah & $\mathrm{U}$ of Utah \\
\hline Maryland & U of Maryland, College Park & Vermont & $\mathrm{U}$ of Vermont \\
\hline Massachusetts & U of Massachusetts, Amherst & Virginia & U of Virginia \\
\hline Michigan & U of Michigan, Ann Arbor & Washington & U of Washington \\
\hline Minnesota & U of Minnesota, Twin Cities & West Virginia & West Virginia U \\
\hline Mississippi & $\mathrm{U}$ of Miss & Wisconsin & U of Wisconsin, Madison \\
\hline Missouri & $\mathrm{U}$ of Missouri, Columbia & Wyoming & U of Wyoming \\
\hline
\end{tabular}

\section{Limitations}

The three chief limitations of this study are media reliability, issues of generalizability given sample size, and reading comprehension measurement accuracy of the TOEFL.

First, all text data were extracted from institutional ".edu" websites: it is possible that some international graduate admissions materials are not featured or are not current on the website, and therefore, these materials may not be included or may not be up to date in this study. Furthermore, given the ease and accessibility of communication technologies since the 1990s, U.S. graduate schools solicit, recruit, and communicate with prospective international graduate students by means outside of the Internet. These communication methods were not analyzed in this study and represent opportunities for future research.

Secondly, because this study is the first of its kind, this study's sample size was limited to the fifty public flagships in the United States: issues of generalizability arise here. Of course, there are thousands of U.S. graduate programs who admit international students every year, and future research should address different types of graduate schools and the readability of their international graduate admissions materials, such as private institutions, satellite campuses, or 
online programs. However, as previously asserted, public flagships and their emphasis on research output was a robust starting point for such a novel investigation.

Finally, the TOEFL has been the most commonly used English language proficiency test administered and used in graduate school admissions since the 1960s, yet, its test makers and takers are human. Subsequently, TOEFL scores may not accurately measure an international graduate student's true reading comprehension level. However, the TOEFL remains an extremely popular method of measuring English language proficiency in the United States - every public flagship accepts the TOEFL—rendering the test an excellent research topic for international graduate student admissions.

Ultimately, this study's importance and inventiveness greatly mitigates its limitations, which are few.

\section{Findings}

A statistical description of minimum TOEFL iBT scores and reading comprehension levels for international graduate student admission at public flagship institutions can be found in Table 2 below.

Table 2. Minimum TOEFL iBT scores and corresponding reading comprehension levels for admission to public flagship universities $(\mathrm{n}=50)$

\begin{tabular}{llll}
\hline & $\begin{array}{l}\text { TOEFL iBT scores } \\
(\max =120)\end{array}$ & $\begin{array}{l}\text { TOEFL iBT reading section } \\
\text { scores }(\max =30)\end{array}$ & $\begin{array}{l}\text { Equivalent reading } \\
\text { comprehension level (grade) }\end{array}$ \\
\hline Mean & 81.6 & 20.3 & $12^{\text {th }}$ \\
Median & 80 & 20 & $12^{\text {th }}$ \\
Mode & 79 & 19.7 & $11^{\text {th }}$ \\
High & 102 & 25.5 & $16^{\text {th }}$ \\
Low & 69 & 17.3 & $10^{\text {th }}$ \\
Range & 33 & n/a & n/a
\end{tabular}

The average minimum TOEFL iBT score required by public flagship universities for international graduate student admission is 81.6 , equating to a 20.3 reading section subscore and a $12^{\text {th }}$-grade reading comprehension level. The most popular minimum TOEFL iBT score was 79 , equating to a 19.7 reading subscore and an $11^{\text {th }}$-grade reading comprehension level. The highest minimum TOEFL iBT score required by public flagship universities for international graduate student admission was 102 , equating to a 25.5 reading subscore and a $16^{\text {th }}$-grade or college senior reading comprehension level. The lowest TOEFL iBT score was 69 , equating to a 17.3 reading subscore and a $10^{\text {th }}$-grade reading comprehension level. The range of scores from highest to lowest was 33 , an unexpected finding.

Grade-level readability measures of international graduate student admissions instructions on public flagship university websites can be found in Table 3 below.

Table 3. Grade-level readability of international graduate student admissions instructions on public flagship university websites $(\mathrm{n}=50)$

\begin{tabular}{lllllll}
\hline \multicolumn{7}{c}{ Readability measures (by grade level) } \\
\hline Mean & ARI & FK & GFI & LEX & SMOG & AVG \\
Median & 14.1 & 14.4 & 13.8 & 16.1 & 15.4 & 14.6 \\
Mode & 14 & 13.9 & 14 & 17 & 15.6 & 14.8 \\
High & 14.1 & 13.9 & 14.7 & 17 & 15.5 & 15.9 \\
Low & 19 & 19 & 18.2 & 17 & 19 & 18.4 \\
& 9.6 & 10.1 & 8.5 & 9 & 10.6 & 10.4
\end{tabular}

The average grade-level readability of international graduate student admissions instructions on public flagship university websites is 14.6, with the Lexile measure being the highest on average at 16.1 and the Automated Readability Index the lowest at 14.1. High and low scores ranged from 19 to 9.6 on the Automated Readability Index, 19 to 10.1 on the Flesch-Kincaid, 18.2 to 8.5 on the Gunning-Fog, 17 to 9 on the Lexile, 19 to 10.6 on the SMOG, and 18.4 to 10.4 on the average: these scores represent nearly ten grade levels of reading comprehension difference between the highest and lowest website readability levels, a surprise of the findings. Furthermore, most (mode) 
international graduate student admissions instructions are written at reading comprehension levels appropriate for a college senior (15.9), another unexpected finding.

\section{Discussion and Implications}

This study reveals that most public flagship universities require incoming international graduate students to read and comprehend at the $11^{\text {th }}$-grade level (per TOEFL iBT reading subscores) but compose their admissions instructions at the $15.9^{\text {th }}$ or college senior reading comprehension level. This problem is exacerbated by the fact that, as mentioned in a previous section, readability measures are written at a $75 \%$ scale, meaning that a text written at the $12^{\text {th }}$-grade reading level is only $75 \%$ comprehended by someone who reads at a $12^{\text {th }}$-grade level. In short, international graduate students are being asked to demonstrate a much lower reading comprehension level on the TOEFL iBT reading section than is required to read a public flagship's website. This of course can result in prospective international graduate students exploring U.S. graduate school websites, per Burdett (2013), and being unable to understand how to apply, thus extinguishing an evitable symbiotic, fruitful academic partnership between the public flagship and an international student. Perhaps the international student has educational resources in their home country or in the United States, yet admissions materials written at college senior levels of reading comprehension would likely hinder the international student's ability to formulate productive questions or overcome linguistic hurdles on the pathway to U.S. graduate school admittance and enrollment.

Therefore, U.S. graduate schools must audit and edit their websites to ensure that their admissions materials are not inadvertently discriminating against international students whose first language is not English. International students, now more than ever, must be given the tools to enter America and thrive in our postsecondary education systems, and public flagship universities should lead the way as they always have in many regards.

Perhaps more troubling is the existence of grade level reading comprehension gap of nearly ten grade levels — varying slightly from measure to measure- between the graduate schools with the easiest and most difficult international graduate admissions requirements. This is problematic for several reasons. Without pinpointing the precise institution, consider an international graduate student from Laos with extended family ties in certain geographic locations in North America. This student may consider U.S. graduate schools closest to their families or support systems, but if these nearby graduate schools compose their admissions instructions and materials at unreadable levels, the international student may be unable to understand how to apply or ask for assistance, thus driving a wedge not only between a student and their education, but a student and their loved ones. In short, there is no reason why one public flagship university composes their graduate admissions instructions at a burdensome $19^{\text {th }}$ - grade reading level, while another composes their instructions at an appropriate 10th grade level. Public flagship universities, along with every public and private institution in America, must operationalize the value of international graduate students by rendering graduate student admissions instructions and materials easier to read and comprehend.

Ultimately, the preliminary research that led to this study was validated: most international graduate student admissions instructions are likely unreadable by the students themselves, a problem that public flagship universities could easily remedy through internal web auditing and editing and a reassessment of how their graduate school addresses, solicits, recruits, and evaluates the international graduate student in online settings.

\section{Conclusion}

Significant results of this study reveal that United States graduate schools require international students to possess English proficiency, yet international graduate student admissions materials are composed at levels largely unintelligible by native speakers of English with advanced degrees. Most public flagship universities require international graduate students to read at the $11^{\text {th }}$-grade level, but international admissions instructions are often composed above the $14^{\text {th }}$-grade reading comprehension level. This is troublesome.

President Trump's Executive Orders have already produced a chilling effect felt by U.S. undergraduate and graduate programs. Paradoxically, the United States has always summoned its strength through an incredible diversity: this strength, this diversity, is now being called into question. As a result, President Trump's actions must catalyze student affairs and admissions professionals working in U.S. institutions to transcend the boundaries placed before them by the current administration and streamline the international student admissions process. Now more than ever before in United States history, higher education must become more equitable and accessible for scholars around the world, hoping to gain admittance to a U.S. institution. These efforts toward increased equity and accessibility can commence by insuring that international graduate admissions materials are readable.

Incontrovertibly, international students in United States postsecondary education systems have never been more vital to the academic, economic, and social health and diversity of the system itself, and by proxy, the United States. The 
time is now to promote the thoroughly American ideology that international students belong in United States graduate programs: facilitating this embodied democracy of postsecondary education, which makes America so beautiful, must begin with simple literacy and the assurance that admissions instructions and materials are readable by current and prospective international students at all education levels.

\section{References}

Advancing Global Higher Education. (2017). Trending topics survey: International applicants for fall 2017, institutional \& applicant perspectives. Retrieved from Advancing Global Higher Education website: http://www.aacrao.org/docs/default-source/TrendTopic/Immigration/intl-survey-results-released.pdf?sfvrsn=0

American Exam Services. (2016). TOEFL score: Minimum scores required by admissions. Retrieved from American Exam Services website: http://www.americanexamservices.com/about-the-toefl/toefl-scores-usa-universities

Anderson, S. (2013, July). NFAP Policy Brief: The importance of international students to America. Retrieved from National Foundation for American Policy website: http://www.nfap.com/pdf/New\%20NFAP\%20Policy\%20Brief\%20The\%20Importance\%20of\%20International $\% 20$ Students\%20to\%20America,\%20July\%202013.pdf

Berdahl, R. M. (1998, October 5). The future of public flagships [Speech transcript]. Retrieved from UC-Berkeley website: http://chancellor.berkeley.edu/chancellors/berdahl/speeches/future-of-flagship-universities

Burdett, K. R. (2013). How students choose a college: Understanding the role of internet based resources in the college choice process (Doctoral dissertation). Available from ProQuest database. (UMI No. 3590306)

Burdick, H., \& MetaMetrics. (2010). The origin of the lexile specification equation. Retrieved from MetaMetrics website:

https://lexile-website-media 2011091601.s3.amazonaws.com/resources/materials/The_Origin_of_the_Lexile_Specification_Equation.pdf

Burton, R. S. (2014). Readability, logodiversity, and the effectiveness of college science textbooks. Journal of College Biology Teaching, 40(1), 3-10. Retrieved from ERIC database. (Accession No. EJ1035554).

Carver, R. P. (1974). Two dimensions of tests: Psychometric and edumetric. American Psychologist, 29(7), 512-518. https://doi.org/10.1037/h0036782

Caylor, J. S., Sticht, T. G., Fox, L. C., \& Ford, J. P. (1973, March). Methodologies for determining reading requirements of military occupational specialties (Research Report No. 73-5). Retrieved from Human Resources Research Organization website: http://files.eric.ed.gov/fulltext/ED074343.pdf

Clark, G. L., Kaminski, P. F., \& Brown, G. (1990). The readability of advertisements and articles in trade journals. Industrial Marketing Management, 19(3), 251-260. https://doi.org/10.1016/0019-8501(90)90017-P

Cline, T. A. (1973). Readability of community college textbooks and the reading ability of the students who use them. Journal of Reading Behavior, 5(2), 110-118. https://doi.org/10.1080/10862967209547033

DuBay, W. H. (2004, August). The principles of readability. Retrieved from ERIC database. (ED490073) Educational Testing Service. (2016). ETS: TOEFL Reports: Test and score data summary for TOEFL iBT tests: January 2015-December 2015. Retrieved from https://www.ets.org/s/toefl/pdf/94227_unlweb.pdf

Ermakova, T., Fabian, B., \& Babina, E. (2015, March). Readability of privacy policies of healthcare websites. Paper presented at Internationale Tagung Wirtschaftsinformatik, Osnabrück, Germany. Retrieved from https://www.researchgate.net/publication/268981590_Readability_of_Privacy_Policies_of_Healthcare_Website $\mathrm{s}$

Fox, M. A. (2001). Flagship institutions, public higher education and research. American Scientist, 89(6), 482. Retrieved from http://www.americanscientist.org/issues/pub/2001/6/flagship-institutions-public-higher-education-and-research

Fry, E. (1986). The varied uses of readability measurement. Annual Meeting of the International Reading Association, pp. 1-14. Retrieved from ERIC database. (Accession No. ED267384) Gunning, R. (1952). The technique of clear writing. New York, NY: McGraw-Hill.

Hendrickson, R. L., Huebner, C. E., \& Riedy, C. A. (2006). Readability of pediatric health materials for preventive dental care. BMC Oral Health, 6(14), 1-9. https://doi.org/10.1186/1472-6831-6-14 
Hossler, D., \& Gallagher, K. S. (1987). Studying student college choice: A three-phase model and the implications for policymakers. College and University, 62(3), 202-221. Retrieved from ResearchGate: https://www.researchgate.net/publication/234741450

Ibrahim, A. M., Vargas, C. R., Koolen, P. G., Chuang, D. J., Lin, S. J., \& Lee, B. T. (2016). Readability of online patient resources for melanoma. Melanoma Research, 26(1), 58-65. https://doi.org/10.1097/CMR.0000000000000210

Institute of International Education. (2016). International students in the United States. Retrieved from Project Atlas: United States website: http://www.iie.org/Services/Project-Atlas/United-States/International-Students-In-US\#.WKhqDhIrJPU

Johnson, K. H. (1972). An analysis of the relationship between readability of Air Force procedural manuals and discrepancies involving non-compliance with the procedures (Master's thesis). Available from ERIC database. (UMI No. ED070941)

Kang, K. (2013, April). Postdocs at federally funded r\&d centers: Fall 2010 (Research Report No. NSF 13-319). Retrieved from NCSES database: https://www.nsf.gov/statistics/nsf13319/pdf/nsf13319.pdf

Kincaid, J. P., \& Delionbach, L. J. (1973). Validation of the automated readability index: A follow-up. Human Factors, 15(1), 17-20. http://dx.doi.org/10.1177\%2F001872087301500103

Kincaid, J. P., Fishburne, R. P., Rogers, R. L., \& Chissom, B. (1975, February). Derivation of new readability formulas (automated readability index, fog count, and flesch reading ease formula) for Navy enlisted personnel (Research Report No. 8-75). Retrieved from US Department of Commerce website: http://www.dtic.mil/dtic/tr/fulltext/u2/a006655.pdf

Kniffin, J. D. (1979). The new readability requirements for military technical manuals. Technical Communication, 26(3), 26-3. Retrieved from http://www.jstor.org/stable/43086724

Ley, P., \& Florio, T. (1996). The use of readability formulas in health care. Psychology, Health \& Medicine, 1(1), 728. https://doi.org/10.1080/13548509608400003

Lopez, D. M., Blobel, B., \& Gonzalez, C. (2016). Information quality in healthcare social media - an architectural approach. Health and Technology, 6(1), 17-25. https://doi.org/10.1007/s12553-016-0131-9

Loughran, T., \& McDonald, B. (2014). Measuring readability in financial disclosures. Journal of Finance, 69(4), 1643-1671. https://doi.org/10.1111/jofi.12162

Lowery, J. C., \& Martin, J. B. (1990). Evaluation of healthcare software from a usability perspective. Journal of Medical Systems, 14(1), 17-29. https://doi.org/10.1007/BF00995877

McClure, G. (1987). Readability formulas: Useful or useless? IEEE Transactions on Professional Communication, 30(1), 12-15. https://doi.org/10.1109/TPC.1987.6449109

McLaughlin, G. H. (1969). Clearing the smog. J Reading, 13(3), 210-211. Retrieved from ERIC database. (Accession No. EJ012666)

Meillier, A., Patel, S., \& Al-Osaimi, A. M. (2015). Readability of healthcare literature for hepatitis b and c. Digestive Diseases and Sciences, 60(12), 3558-35562. https://doi.org/10.1007/s10620-015-3808-4

MetaMetrics. (2007). The Lexile framework for reading: Implementation resource manual [Pamphlet]. Retrieved from https://www.azed.gov/wp-content/uploads/PDF/FAQ_WhatdoestheLMmean.pdf

MetaMetrics. (2016). Text complexity grade bands and lexile bands. Retrieved from The Lexile Framework for Reading website: https://lexile.com/using-lexile/lexile-measures-and-the-ccssi/text-complexity-grade-bands-and-lexile-ranges/

Milne, G. R., Culnan, M. J., \& Greene, H. (2006). A longitudinal assessment of online privacy notice readability. Journal of Public Policy \& Marketing, 25(2), 238-249. https://doi.org/10.1509/jppm.25.2.238

Mirsky, J. B., Tieu, L., Lyles, C., \& Sarkar, U. (2015). Readability assessment of patient-provider electronic messages in a primary care setting. Journal of the American Medical Informatics Association, 23(1), 202-206. https://doi.org/10.1093/jamia/ocv087

Pandit, K. (2007). The importance of international students on our campuses. Yearbook of the Association of Pacific Coast Geographers, 69(2007), 156-159. https://doi.org/10.1353/pcg.2007.0012 
Peng, C.-C. (2015). Textbook readability and student performance in online introductory corporate finance classes. Journal of Educators Online, 12(2), 35-49. Retrieved from ERIC database. (Accession No. EJ1068379). https://doi.org/10.9743/JEO.2015.2.6

Schlief, M., \& Wood, R. W. (1974). A comparison of procedures to determine readability level of non-text material. Reading Improvement, 11(2), 57-65. Retrieved from ERIC database. (Accession No. EJ103983)

Schneider, D. E. (2011). Assessing the readability of college textbooks in public speaking: Attending to entry level instruction. Communication Teacher, 25(4), 246-255. https://doi.org/10.1080/17404622.2011.601727

Shepherd, M. D., Selden, A., \& Selden, J. (2011, April). Possible reasons for students' ineffective reading of their first-year university mathematics textbooks (Research Report No. 2011-2). Retrieved from Tennessee Technological University website: http://files.eric.ed.gov/fulltext/ED519031.pdf

Sticht, T. G. (1970, October). Literacy demands of publications in selected military occupational specialties (Research Report No. 25-70). Retrieved from ERIC database. (Accession No. ED044615)

Sticht, T. G., \& Zapf, D. W. (1976, September). Reading and readability research in the armed forces (Research Report No. 76-4). Retrieved from Air Force Office of Scientific Research website: http://eric.ed.gov/?id=ED130242

Strong, R. A. (1986). Using Gunning's fog index with term papers and outside reading lists. Journal of Financial Education, 15, 63-67. Retrieved from JSTOR database: http://www.jstor.org/stable/41948096

Trump, D. J. (2017a, January 25). Executive order: Border security and immigration enforcement improvements. Retrieved from The House website: https://www.whitehouse.gov/the-press-office/2017/01/25/executive-order-border-security-and-immigration-enf orcement-improvements

Trump, D. J. (2017b, January 25). Executive order: Enhancing public safety in the interior of the United States. Retrieved from The White House website: https://www.whitehouse.gov/the-press-office/2017/01/25/presidential-executive-order-enhancing-public-safetyinterior-united

Trump, D. J. (2017c, January 27). Executive order: Protecting the nation from foreign terrorist entry into the United States. Retrieved from The White House website: https://www.whitehouse.gov/the-press-office/2017/01/27/executive-order-protecting-nation-foreign-terrorist-ent ry-united-states

The University of Texas at Austin Graduate School. (2017). International students: How to apply. Retrieved from The University of Texas at Austin website: https://gradschool.utexas.edu/admissions/how-to-apply/international-students

Walfish, S., \& Watkins, K. M. (2005). Readability level of health insurance portability and accountability act notices of privacy practices utilized by academic medical centers. Evaluation \& The Health Professions, 28(4), 479-486. https://doi.org/10.1177/0163278705281080

Wendler, C., Cline, F., Sanford, E., \& Aguirre, A. (2010). ETS: Research \& Development: Providing additional meaning to TOEFL $i B T$ reading scores. Retrieved from Educational Testing Service website: http://www.ealta.eu.org/conference/2010/docs/Posters/Wendler_ea.pdf

Wong, I. C. (1999). Readability of patient information leaflets on antiepileptic drugs in the UK. Seizure, 8(1), 35-37. https://doi.org/10.1053/seiz.1998.0220 